\title{
UMBILICAL REGION AFFECTIONS IN RUMINANTS
}

\author{
M. I. YASIN, MOHAMmed S. MOHAMmed and N.J. HASSAN \\ Dept. of medicine and surgery, College of Veterinary Medicine, University of Duhok, Kurdistan Region-Iraq.
}

(Received: November 6, 2017; Accepted for publication: December 28, 2017)

\begin{abstract}
The aim of the present study is to describe the clinical signs and methods for treatment of 32 cases of umbilical region affections in ruminants recorded during a period of 4 years. Umbilical hernias were the most common umbilical region affection recorded $(\mathbf{4 6 . 8 \%})$ especially in female lambs followed by omphalocele (25\%), abscesses $(18.8 \%)$ and patent urachus $(9.4 \%)$.

Umbilical hernias, omphalocele, patent urachus were congenital detected by the animals' owners shortly after birth. Abscesses were acquired recorded in adult animals, the pus was found only in the subcutaneous part of the umbilical region. Umbilical hernias, abscesses, and patent urachus were surgically repaired with no post operative complication. For omphalocele, high mortality rate was recorded and only one animal survived surgery.
\end{abstract}

KEYWORDS: Umbilical region, Patent urachus, Umbilical hernia, Omphalocele, Ruminants

\section{INTRODUCTION}

The umbilical region is that area which surrounds the umbilicus. Different diseased conditions of the umbilical region have been described in ruminants especially in bovine, some of them are congenital related to abnormalities of the umbilical cord detected soon after birth like congenital umbilical hernias, omphalocele, and patent urachus (Mosbah and Karrouf 2006; Alam and Rahman, 2008; Parrah et al., 2013); other affections are acquired like acquired umbilical hernia, navel ill, and umbilical region abscesses (Ganga et al., 2011; Saker et al.,2014) .

Both Omphalocele (exomphalos or open umbilical hernia) and umbilical hernia are midline abdominal wall defects at the base of the umbilicus with herniation of the abdominal contents.

During intrauterine fetal development, the midgut normally herniate from the abdominal cavity and occupies part of the extra-embryonic coelom called the umbilical sac. This occurs around the third to the fourth week of gestation in cattlte, sheep, dogs and pigs, the herniated content then return back into the abdominal cavity. If the midgut remains in the umbilical sac and fail to return to the abdomen, omphalocele will occur (McGready et al.,2006).

In umbilical hernia, the herniated contents are covered internally by parietal peritoneum and externally by intact skin while in omphalocele the herniated contents are covered by a semi translucent sac composed of inner parietal peritoneum and an outer layer of amniotic membrane which, in most cases, ruptured during or shortly after birth because it is very delicate and it lacks skin covering (Morris and Malt, 1994; Williams et al., 2008) exposing the herniated organs to severe contamination and damage.

There are two types of omphalocele; omphalocele minor in which the abdominal defect is $5 \mathrm{~cm}$ long and the eviscerated organ is only the intestine and omphalocele major where the abdominal defect is more than $5 \mathrm{~cm}$ long and contain the liver with the intestine (Morris and Malt, 1994; Williams et al., 2008).

The urachus is a tube that drains urine from the urinary bladder of the fetus to the amniotic sac during embryonic development. Patent urachus is a congenital defect characterized by dribbling of urine from the umbilicus due to failure of urachus to close at birth (Jubb and Kennedy, 1970; Vaughan et al., 1988).

Abscesses may occur as a result of a wound when pathogenic organisms become imprisoned in any subcutaneous tissues (Greenough and Johnson, 1988).

The purpose of the present article is to describe the clinical signs, treatment and prognosis of several cases of congenital and acquired umbilical region affections in ruminants. 


\section{MATERIALS AND METHODS}

Thirty two animals with different umbilical region diseased conditions were presented to the veterinary teaching hospital of the College of Veterinary Medicine/Dohuk University/ Kurdistan region/Iraq over a period of 4 years (from January 2012 to April 2016).

The signalment (species, age, and sex) of the animals and history of these diseases were registered. The diagnosis was based on the history, clinical signs, physical examination, palpation of the umbilical region and aseptic needle aspiration.

The diseased condition which needed a surgical interference was performed under aseptic condition by local infiltration anesthesia using $2 \%$ lidocaine hydrochloride (pil, India). Procaine penicillin and dihydrostreptomycin sulphate (Pen \& Strep ${ }^{\circledR}$ Norbrook G.B.) was administered one hour before any surgical interference and continued for 4 days thereafter. Skin sutures were removed at the tenth postoperative day.

For treating umbilical hernia, a linear skin and subcutaneous tissue incision was made in the center of each hernial sac to expose the hernial ring, the adhesions between the hernial content and the ring was removed, the contents were replaced into the abdominal cavity and the ring was closed by modified overlapping horizontal mattress using No. 1-2 polypropylene. The subcutaneous tissue was closed with simple continuous No.0 polyglycolic acid. The skin was closed by simple interrupted No.0 polypropylene.

Treatment of omphalocele with intact sac was similar to that of umbilical hernias. For omphaloceles with ruptured sacs, the eviscerated contents was flushed with warm sterile normal saline to remove all the debris and contaminations and then replaced into the abdominal cavity. Closure of the abdominal defect was similar to that used to close umbilical hernial ring. The subcutaneous tissue and skin edges around the closed abdominal defect was debrided and closed similar to that in umbilical hernia.

Abscesses were differentiated from umbilical hernias by placing the animals on supine position, no reduction of the size of the swelling was noted and no hernial ring was palpated. Diagnosis was conformed by aseptic needle puncture and aspiration of pus. Treatment of the abscesses involved lancing the skin over the center of the abscess to drain the pus and remove all the necrotic tissues with irrigation of the abscess cavity by povidone iodine. The abscess cavity was then packed with povidone iodine soaked gauze and systemic antibiotic (Pen \& Strep ${ }^{\circledR}$ ) was given. The treatment was repeated daily until the cavity became small and no pus was drained.

Patent urachus was treated by ventral midline abdominal incision where the urachus was isolated, dissected to the urinary bladder and resected. The opening in the urinary bladder was closed by two inverting layers (Connell followed by Cushing pattern) using No.2-0 polyglycolic acid. All the damaged and necrotic subcutaneous tissue was removed and the abdominal wall was closed as usual.

Skin stitches were removed at the 10th post operative day in all animals survived the surgical repair.

\section{RESULTS}

Thirty two animals with different umbilical region affections were recorded. The type of affection, the species and the se $\mathrm{x}$ of the animals is shown in table 1.

Nineteen $(59.4 \%)$ animals were sheep, eight $(25 \%)$ were goats, and $5(15.6 \%)$ were cattle.

Twenty five were females (17 sheep, 5 goats and 3 cattle); and 7 were males ( 2 sheep, 3 goats, and male 2 cattle). 
Table(1): Distribution of the umbilical region affections on the basis of the species and sex of the animals. $P=$ female, $\hat{o}=$ male

\begin{tabular}{|c|c|c|c|c|c|c|}
\hline \multirow{2}{*}{\multicolumn{2}{|c|}{ Species/Sex }} & \multicolumn{4}{|c|}{ Umbilical region affection } & \multirow{4}{*}{$\begin{array}{l}\text { Total } \\
17 \\
2 \\
\end{array}$} \\
\hline & & \multirow{2}{*}{$\begin{array}{l}\text { Umbilical hernia } \\
8 \\
\end{array}$} & \multirow{2}{*}{$\begin{array}{l}\text { omphalocele } \\
4\end{array}$} & \multirow{2}{*}{$\begin{array}{l}\text { Persistent urachus } \\
2\end{array}$} & \multirow{2}{*}{$\begin{array}{l}\text { Abscess } \\
3 \\
\end{array}$} & \\
\hline Sheep & q & & & & & \\
\hline & $\hat{0}$ & 2 & - & - & - & \\
\hline \multirow[t]{2}{*}{ Goat } & q & 2 & 2 & - & 1 & 5 \\
\hline & $\hat{0}$ & 2 & - & 1 & - & 3 \\
\hline \multirow[t]{2}{*}{ Cattle } & q & - & 2 & - & 1 & 3 \\
\hline & $\hat{0}$ & 1 & - & - & 1 & 2 \\
\hline Total & & 15 & 8 & 3 & 6 & 32 \\
\hline
\end{tabular}

Of the 32 cases, $15(46.8 \%)$ were umbilical hernia (fig.1) and were most frequently recorded in female sheep. All the animals were in good physical condition, their ages ranged between 13 months for most animals, 6 months in a male calf and 3-5 years in four ewes. All these hernias were noticed by the owners early in animal life but some cases were neglected until the animal became adult and the hernia became very large. All the hernias were reducible. The herniated contents were the omentum and the intestine. Adhesions of the contents with the ring and the inner surface of the hernial sac were noted. All hernias were successfully repaired with no record of

reherniation.

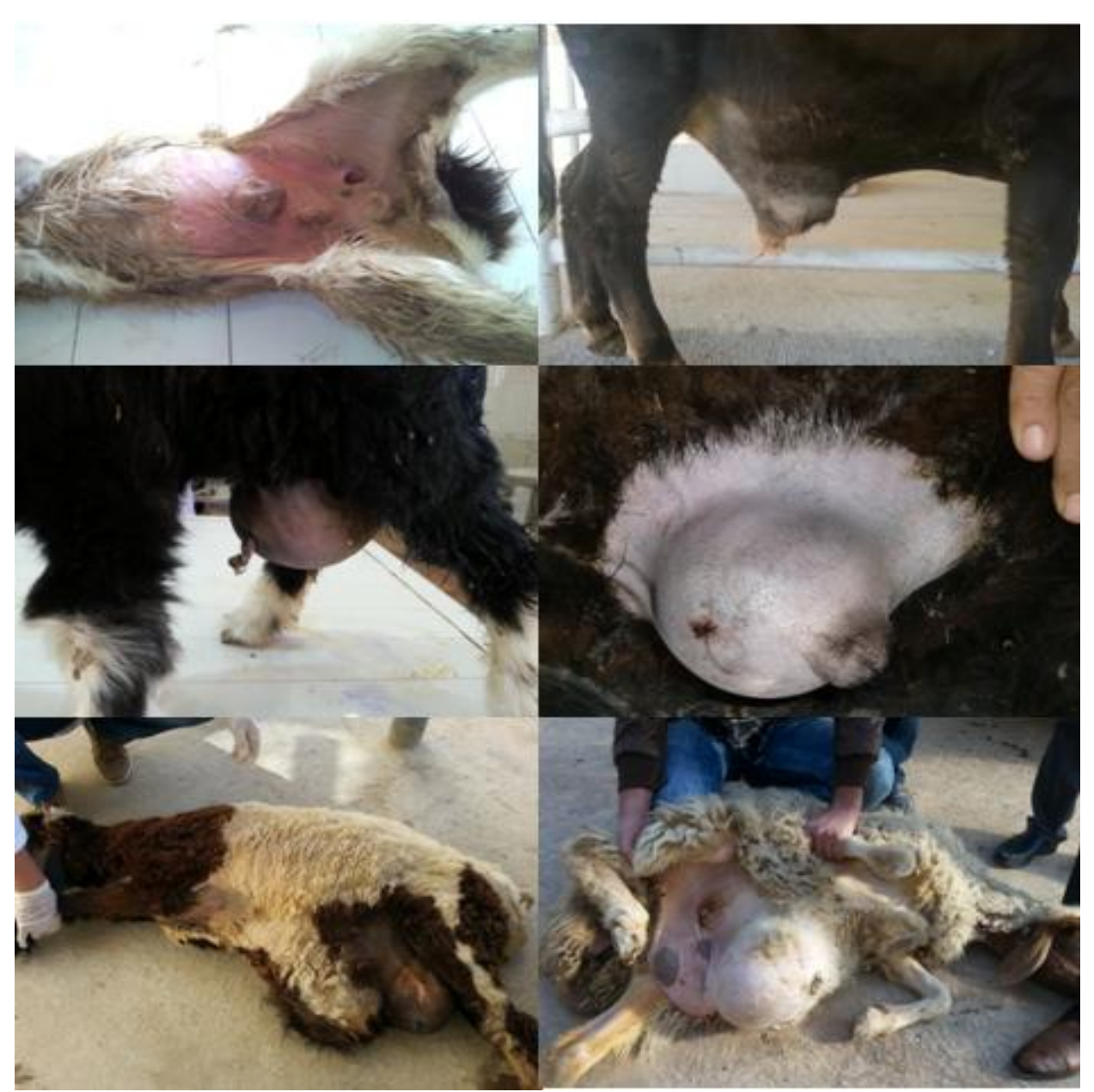

Fig, (1): Umbilical hernias in ruminants. 
Omphalocele were the second most common affection recorded in 8 (25\%) full term females (4 lambs, 2 kids and 2 calves). Omphalocele minor with ruptured sacs was recorded in six animals, their ages ranged from 5-12hours (fig.2), with contamination of the herniated contents (only intestine) with mud and feces causing severe inflammation, edema and thickening of the wall of the intestine. The abdominal defect was $4-6 \mathrm{~cm}$ long. These animals were hypothermic, unable to stand or suckle and all died few hours after the repair.

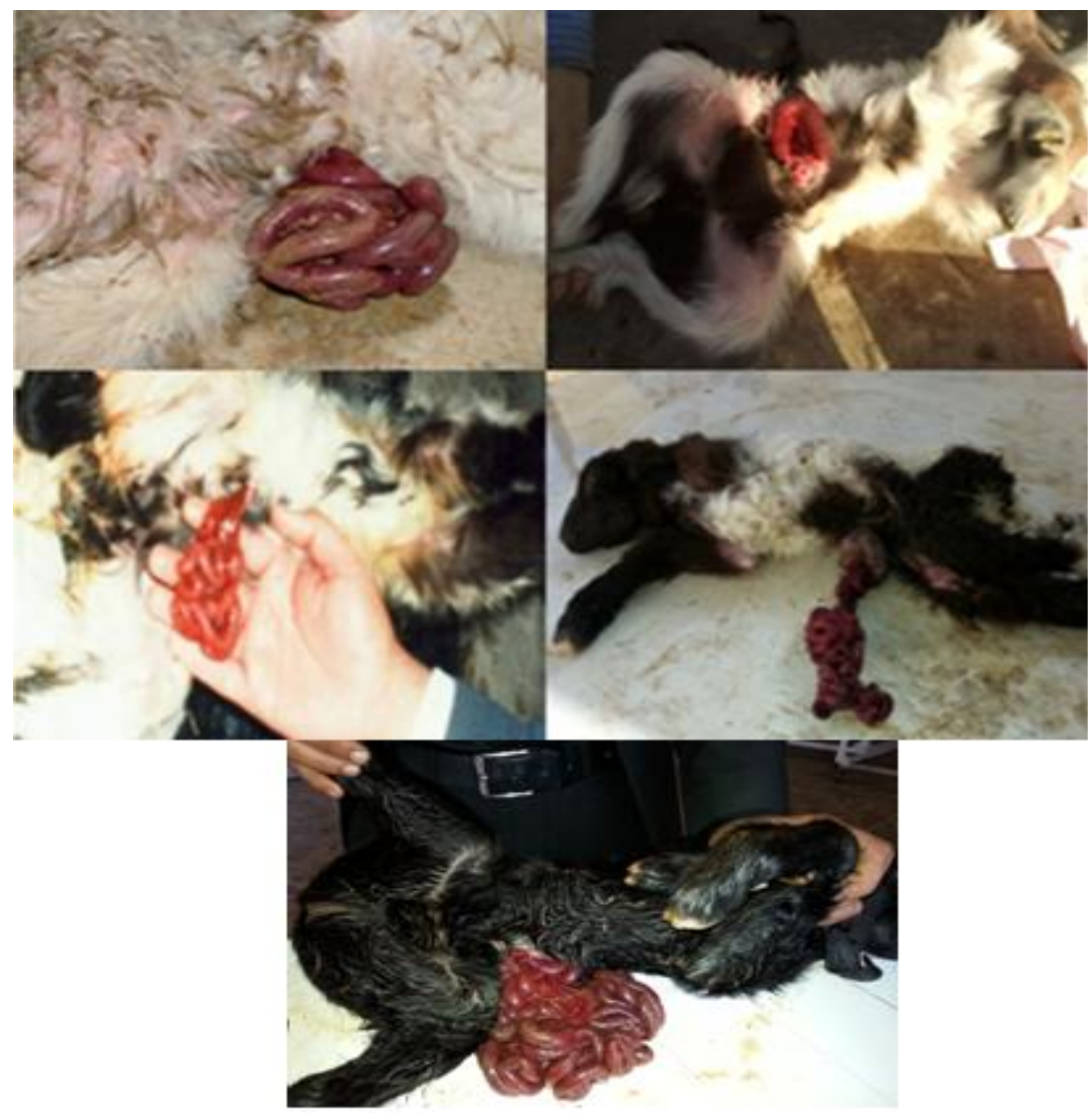

Fig. (2): Cases of omphalocele with ruptured sac.

In the two remaining animals (a 2 weeks old calf and a 4 days old lamb) the covering sac was intact. In the calf, omphalocele major was recorded and the liver was found and protected by the intact sac from external contamination (fig.3). The animal had no systemic reaction and suckles milk normally. The abdominal wall defect $(7 \mathrm{~cm}$ long) was enlarged cranially to facilitate gentle replacement of the liver into the abdominal cavity behind the diaphragm. No postoperative complication was recorded and the animal survived surgery. 


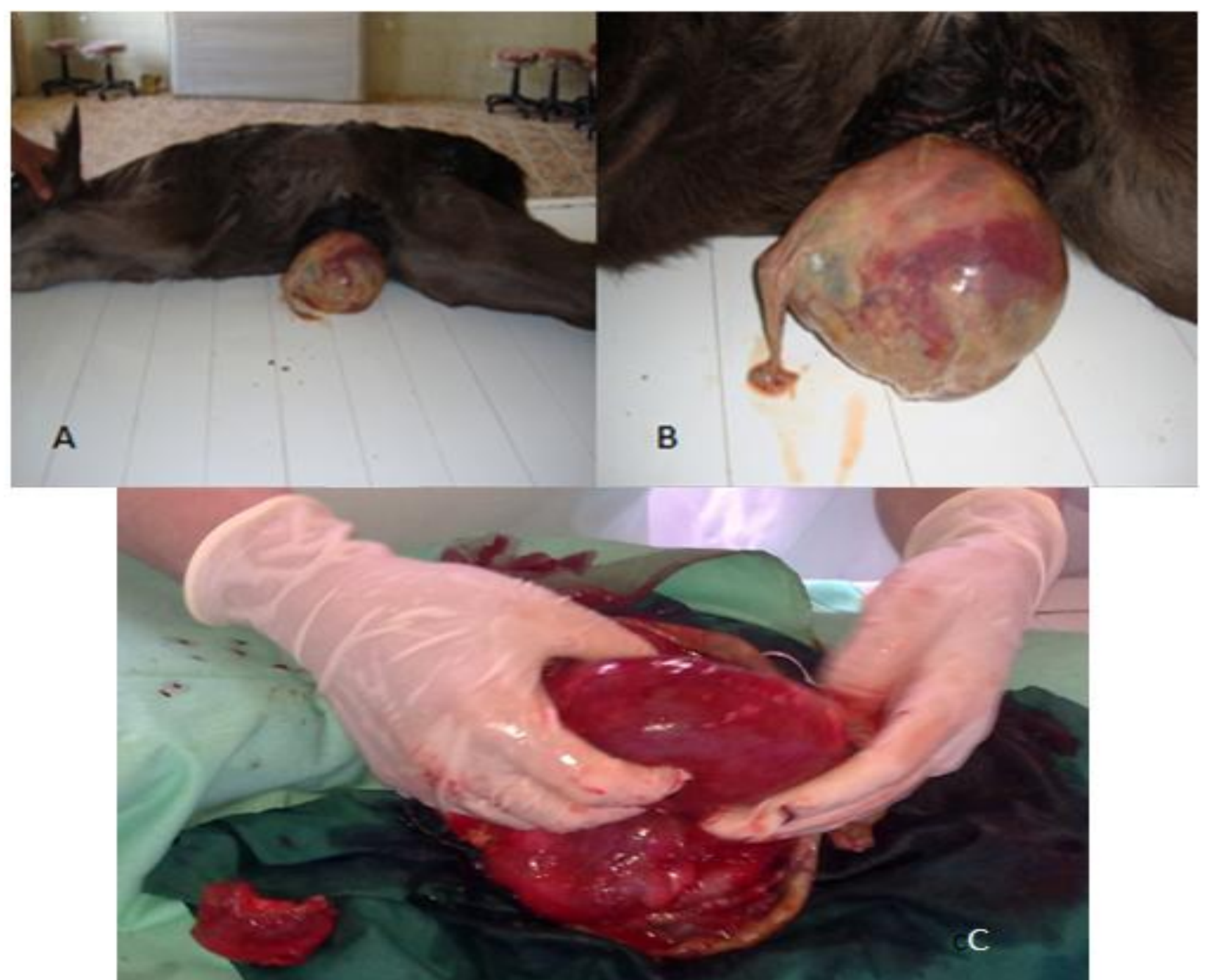

Fig. (3): Omphalocele major in a calf (A) with intact sac (B) containing liver (C).

The omphalocele in the lamb contain a lobe of liver (fig.4). the abdominal defect was about $4 \mathrm{~cm}$ long. The animal also had atresia ani with abdominal distention and was recumbent, unable to stand and died after the operation. Data collected from the owners concerning the health status and nutrition of the dam and medication given during pregnancy did not provide the exact cause of omphalocele.

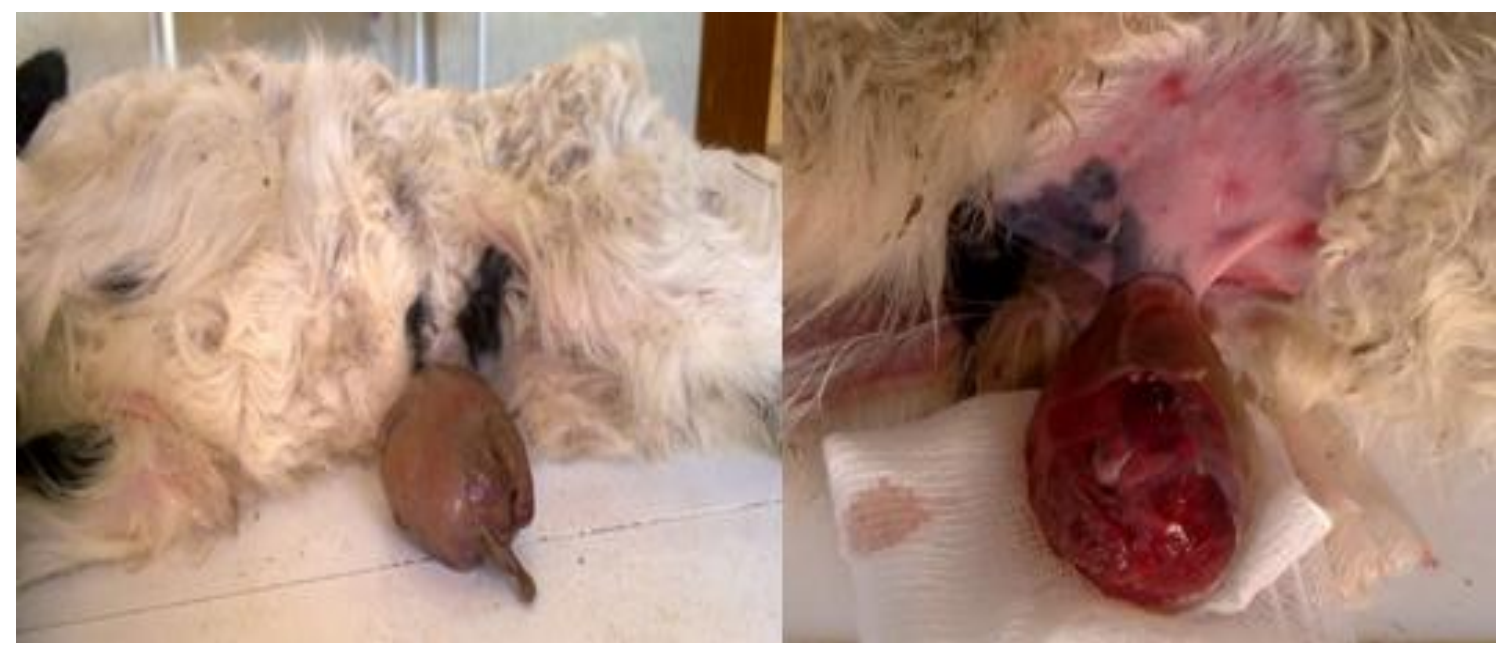

Fig. (4): Omphalocele with intact sac in a lamb containing a lobe of liver 
Six cases $(18.8 \%)$ of abscesses were recorded (fig.5) seen only in adult animals except in one, 3 month old, calf. On palpation, the unbilical swellings were hot flactuated, and painful. The diameter of the abscesses varied, and in one doe, the diameter was about $25 \mathrm{~cm}$ extending caudally to the prepubic region. No systemic reaction was recorded in all animals and the pus was confined only in the subcutaneous tissue of the umbilical region with no communication with the abdominal cavity. Pus samples from the abscesses for culturs and identification of the causative agents was not performed.

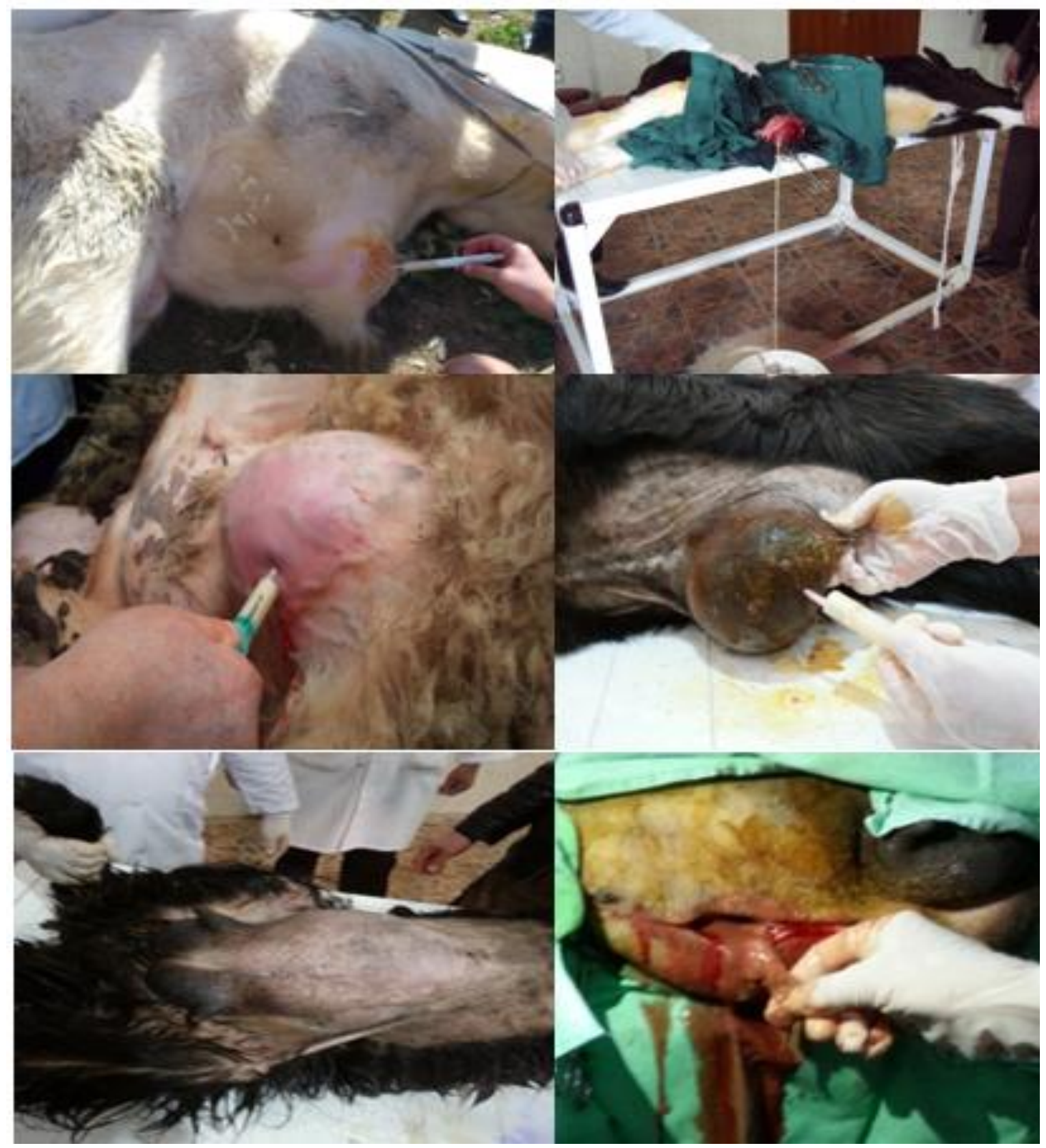

Fig. (5): Abscesses in the umbilical region.

Three cases (9.4\%).of patent urachus were recorded in a 5 and 7 days old female lambs and a 20 days old male kid. Normal urination from the urethra was confirmed before surgical correction. In the 3 day old lamb, the region from the umbilicus to the pubis was devoid of skin forming a large ventral abdominal defect. The subcutaneous tissue at the umbilical region was severely inflamed and scald by the urine (fig.6). All the damaged tissue was resected with the urachus and the skin from both sides of the defect was approximated by simple interrupted No.0 polypropylene 


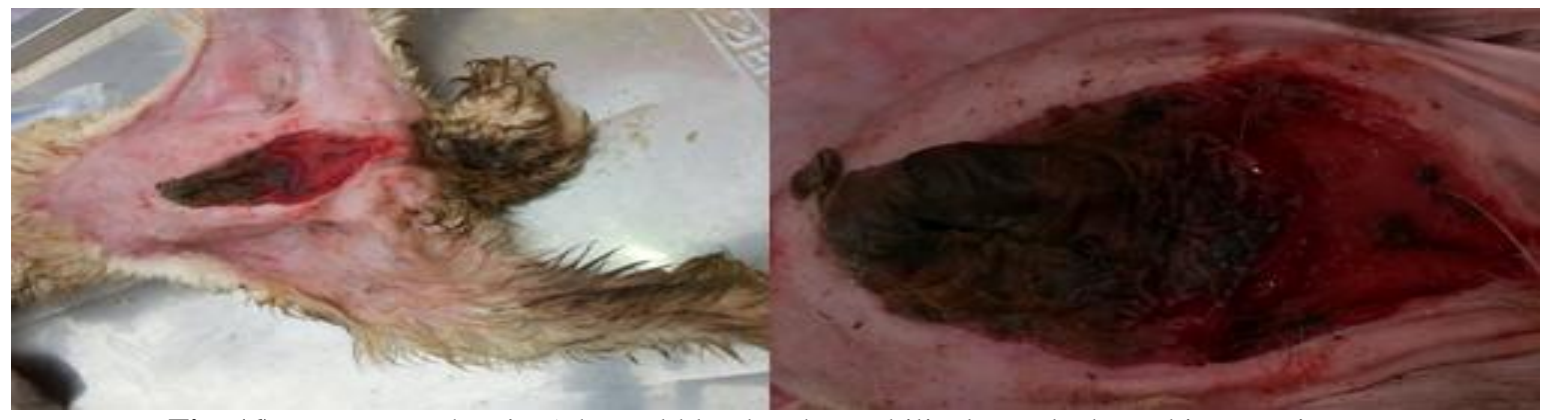

Fig. (6): Patent urachus in 5 days old lamb. The umbilical area lacks a skin covering.

In the male kid, urine was aseptically aspirated from an umbilical swelling (fig.7A). When the swelling was surgically opened, patent urachus was detected with severe inflammation and fibroses of the subcutaneous tissue due to accumulation of urine under the skin (fig.7B). The opening of the urachus was identified (Fig 7C).

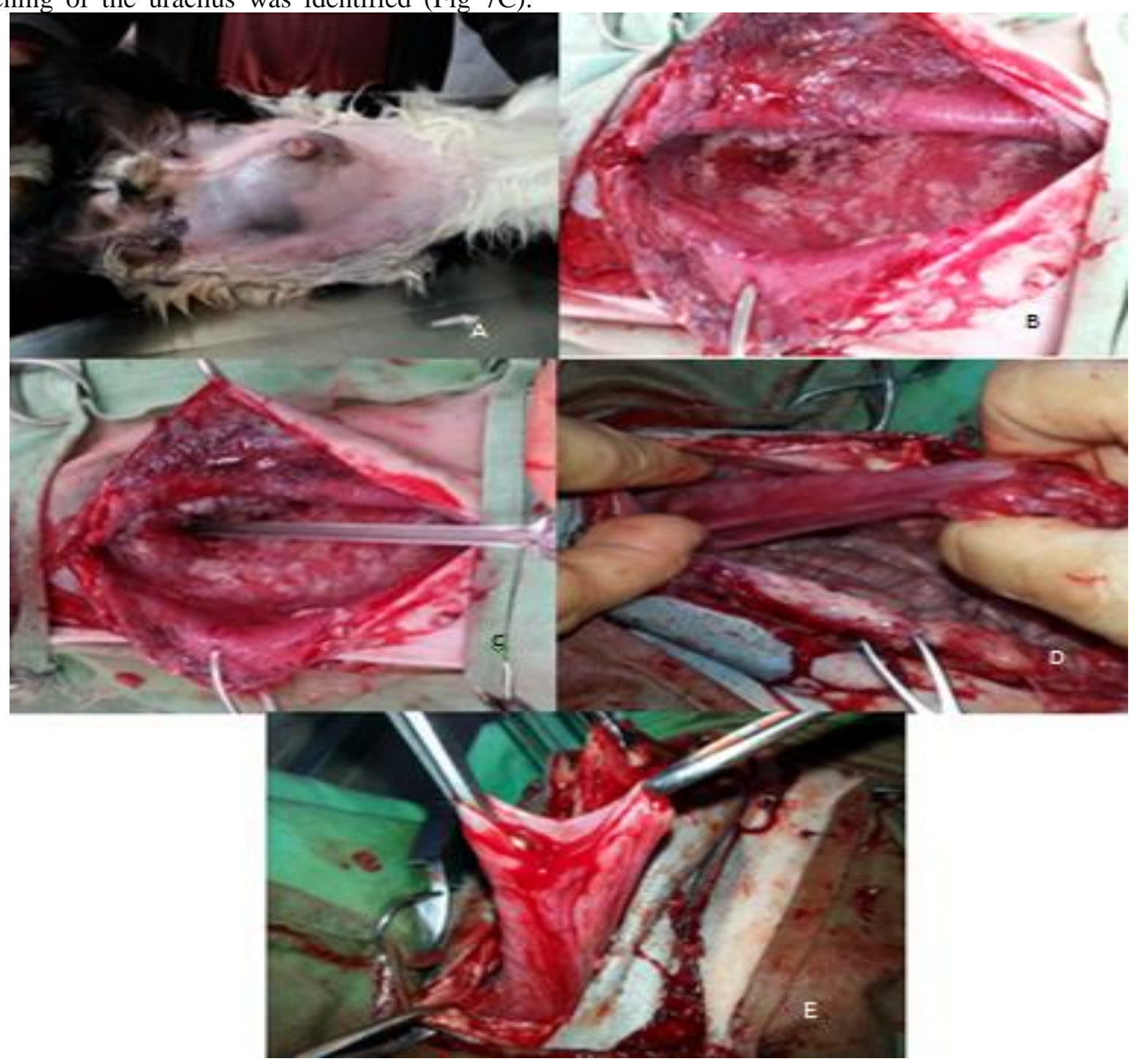

Fig. (7): Patent urachus in a male kid
The urachus was isolated and resected from the urinary bladder (fig. 7D and E). The bladder was closed by two rows of inverting patterns. All inflamed and necrotic subcutaneous tissue and skin were removed and the abdominal cavity is closed. 


\section{DISCUSSION}

In the present study, four types of umbilical region affection have been recorded, these were umbilical hernias, omphalocele, patent urachus, and abscesses. Umbilical hernia was the most frequent affection noted. This finding is in agreement with other studies that noted that umbilical hernias were the most frequent surgical cases recorded in ruminants (Alam and Rahman, 2008; Saker et al., 2013; Moscuzza et al., 2014; and Saker et al., 2014).

All umbilical hernias recorded in this study were congenital seen shortly after birth and were devoid of infection or abscessation. It was mainly recorded in female lambs, but in some cases, the animals were neglected until they became adult and the hernias enlarged in size which may be due to increased intra abdominal pressure caused by multiple pregnancies.

Congenital umbilical hernias occur due to failure of the umbilical ring to close early in animal life. They are considered to be inherited and having a genetic component related to the sex and certain breeds of sheep (Scott, 2012), and many cattle breeds (Herrmann et al., 2001; Masakazu, 2005), to decrease the frequency of congenital umbilical hernias, affected animals should not be used for breeding purposes (Nelson, 1988).

Omphalocele is a fatal defect carrying a poor prognosis especially if the covering sac is teared and if another congenital defect is found. In this study, all animals with uncovered omphalocele died due to severe damage of the eviscerated contents. This result is in agreement with that recorded by Yasin et al., 2006, where the mortality rate in animals with omphalocele was about $77 \%$ and all dead animals had uncovered omphalocele.

The cause of omphalocele in animals is not known. In this study, informations gathered from the case history of the animals regarding administration of drugs, feeding, and the health status of the dam during pregnency were not useful in detecting the the cause of omphalocele. In human, several causes have been accused to be resposable for the occurance of omphalocele. Heridetery and genetic disorders due to the presence of chromosomal anomalies like trisomy 13 and 18 is believed to be the cause of some cases of omphalocele (Nyberg et al., 1989; Kanagawa et al.,2002; Yatsenko et al.,2003).
Hyperthermia and febrile illness during pregnancy was also accused to be the cause of omphalocele (Edwards, 1986; Edwards et al., 1995). Other studies showed that exposure to toxic chemicals and environmental contamination were the causes of omphalocele in human (Croen et al., 1997; Vrijheid, 2000 ).

Other studies showed that the frequency of omphalocele increases with increased maternal age (Tamparo and Lewis, 2011).

Patent urchus occurs due to failure of the urachus to close at birth either due to some congenital defect that prevent closure, or due to omphalitis and infectione in the umbilical vein and arteries (Vaughan et al., 1988). If not treated, patent urachus will causes retrograde infection causing abscess formation, peritonitis and cystitis (Vaughan et al., 1988).

\section{REFERENCES}

- Alam, M. and Rahman, M (2008). Surgical repair of congenital anomalies in ruminants in two different region of Bangladesh. IJVS. 3(4):6774.

- Croen, L.A.; Shaw, G.M.; Sanbonmatsu, L.; Selvin, S.; Buffler, P.A. (1997). Maternal residental proximity to hazardous waste sites and risks for selected congenital malformation. Epidemiology. 8(4): 347-354.

- Edwards, M.J. (1986). Hyperthermia as a teratogen: a review of experimental studies and clinical significances. Teratog. Carcinog. Mutagen. 6(6):563-582.

- Edwards, M.J.; Shiota, K.; Smith, M.S.R.; Walsh, D.A. (1995). Hyperthermia and birth defect. Reprod. Toxicol. 9(5): 411-425.

- Ganga, N.S.; Ananda, K.J.; Kavitha, R.B.; Kotresh, A.M.; Shambulingappa, B.E.; Patel, S.R. (2011). Navel ill in new born calves and its successful treatment. Vet world.4(7): 326-327

- Greenough, P.R. and Johnson, L. (1988). Abscessation. In: Textbook of large animal surgery. Edited by Oehme, F.W. $2^{\text {nd }}$ edition. Williams \& Wilkins Co. Baltimore. pp: 173-174

- Herrmann, R; Utz, J.; Rosenberger, E.; Doll, K.; Distl, O. (2001). Risk factors for congenital umbilical hernia in German Fleckvieh. The Vet. J. 162:233-240

- Jubb, K.V.F. and Kennedy, P.C. (1970). The pathology of domestic animals. $2^{\text {nd }}$ edition. Academic press. New York. pp: 310

- Kanagawa, S.L.; Begleiter, M.L.; Ostlie, D.J.; Holcomb, G.; Drake, W.; Butler, M.G. (2002). Omphalocele in three generations with 
autosomal dominant transmission. J. Med. Genet. 39(3):184-185

- Masakazu, S. (2005). Umbilical hernia in Japanese black calves: A new treatment technique and its hereditary background. J. Live Med. 507:543547.

- McGeady, T.A.; Quinn, P.J.; Fitzpatrick, E.S.; Ryan, M.T.; Cahalan,S. (2006). Digestive system. In: Veterinary embryology. Blackwell. Oxford, UK. pp 217-221.

- Morris, P. J. and Malt, R.A. (1994). Hernias of the abdominal wall. In: Oxford textbook of surgery. Oxford medical pub. Vol.1 pp: 1408

- Mosbah, E. and Karrouf, G. (2006). Surgical management of certain umbilical affections in calves and foals. Minufiya Vet. J. 4(2): 249-270

- Nelson, D.R. (1988). Hernias. In: Textbook of large animal surgery. ${ }^{\text {2nd }}$ edition. Edited by Oehme, F.W. Baltimore: Williams \& Wilkins. pp: 390394.

- Nyberg, D.A.; Fitzsimmons, J.; Mack, L.A.; Hughes, M; Pretorius, D.H.; Hickok, D.; Shepard, T.H. (1989). Chromosomal abnormalities in fetuses with omphalocele. Significance of omphalocele contents. J. Ultrasound Med. 8(6): 299-308

- Parrah, J.D.; Moulvi, B.A.; Athar, H.; Mir, M.S.; Mehraj, u din; Gazi, M; Handoo, N. (2013). A retrospective study on surgical affections of young calves. J. Advanced Vet. Res. 3: 77-82.

- Saker, N.U.; Rahman, M.M.; Rana, M.S.; Islam, M.T.; Rima, U.K. (2013). Prevalence of surgical diseases of cattle in stall-fed and free-range cattle in Bangladish. Bangladish Veterinarian. 30: 62-69.

- Saker, N.U.; Samaddar, K.; Haq, M.M; Rahman, M.M. (2014). Surgical affections of cattle in milk-shed areas of Bangladesh. The Bangladesh Veterinarian. 31(1): 38-45.

- Scott, P. (2012). Some common genetic defects in sheep. Livestock 17(2):42-45.

- Tamparo, C.D. and Lewis M.A.(2011). Omphalocele. In: Diseases of the human body. Fifth edition. F.A. Davis Com. Philadelphia. pp:124

- Vrijheid, M. (2000). Health effects of residence near hasardous waste landfill sites. A review of epidemiologic literature. Environ. Health Perspect. 108(Suppl 1):101-112.

- Vaughan, J.T.; Walker, D.F.; Ames, N.K.; Powe, T.A. (1988). Persistent urachus. In: Textbook of large animal surgery. Edited by Oehme, F.W. $2^{\text {nd }}$ edition. Williams \& Wilkins Co. Baltimore. pp : 524-525

- Williams, N.S.; Bulstrade, C.J.K.; Oconnell, P.R. (2008). Umbilical hernia. In: Bailey \& Love's Short practice of surgery. $25^{\text {th }}$ ed. Hodder Arnold. UK. pp: 980.

- Yasin, M.I.; Hassan, N.J.; Abdulraheem, S.A. (2006). Omphalocele in ruminants. J. Dohuk Univ. 9(2): 179-182

- Yatsenko, S.A.; Mendoza-Londono, R; Belmont, J.W.; Shaffer, L.G. (2003). Omphalocele in trisomy 3q: further delineation of phenotype. Clin. Genet. 64(5):404-413. 
توشبوونا نهخوشييّن نافك ودمورو بهريّن ويى د تهرش وتهوالى دا

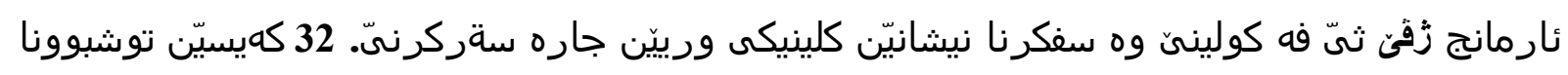

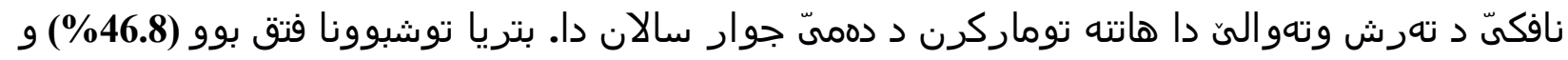

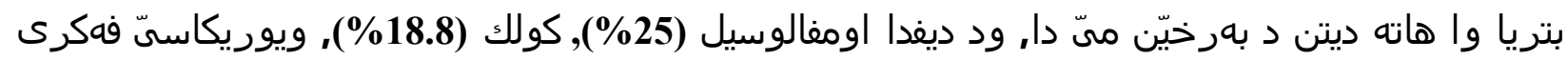

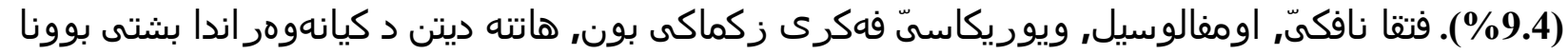

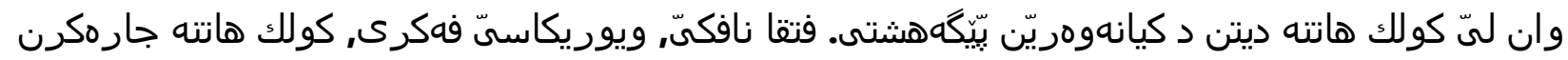

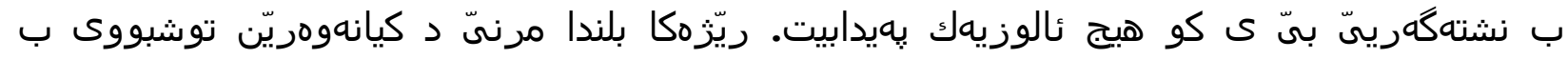
اومفالوسيل هاتهتوماركرن.

ألأصابات المرضية لمنطقة السرة في المجترات

الخلاصة

الهدف من هذه الدراسة هو وصف العلامات السريرية و طرق عات الاج 32 حالة أصابة في منطقة السرة

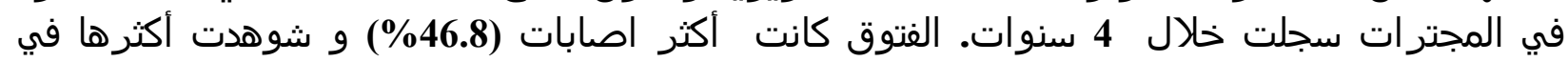

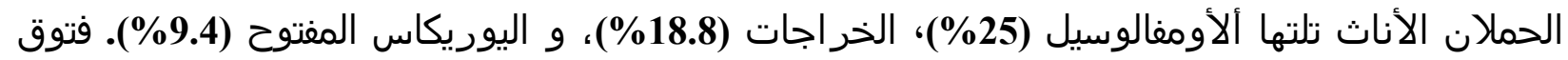

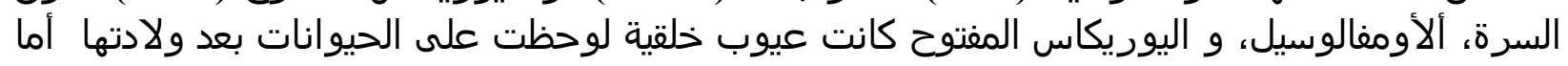
الخراجات فقد وجدت في الحيوان الحيوانات البالغة. تم علاج فتوق السرة، اليوريكاس المفتوح، و الخرات الخاتات الخات جراحيا" بدون ظهور أي مضاعفات و سجلت نسبة عالية من الهاكات في الحيوان اليوان المصابة بألأمفالوسيل. 